\title{
Isolation of Microcystins from the Cyanobacterium Planktothrix rubescens Strain No80
}

\author{
Timo H. J. Niedermeyer $\cdot$ Peter Schmieder $\cdot$ Rainer Kurmayer
}

Received: 15 October 2013/Accepted: 22 November 2013/Published online: 18 February 2014

(C) The Author(s) 2014. This article is published with open access at Springerlink.com

\begin{abstract}
Three minor microcystins have been isolated from a Planktothrix rubescens strain. Their structures have been elucidated by one- and two-dimensional NMR spectroscopy and high-resolution tandem mass spectrometry as the compounds $\left[\mathrm{Asp}^{3},(E)-\mathrm{Dhb}^{7}\right] \mathrm{MC}-\mathrm{LY}(\mathbf{1}),\left[\mathrm{Asp}^{3},(E)-\mathrm{Dhb}^{7}\right] \mathrm{MC}-\mathrm{HtyW}(\mathbf{2})$, and $\left[\mathrm{Asp}^{3},(E)-\mathrm{Dhb}^{7}\right] \mathrm{MC}-\mathrm{LW}(\mathbf{3})$. The amino acids found at the variable positions 2 and 4 of the microcystin core structure are in accordance with the predicted amino acid substrate activation selectivities of the non-ribosomal peptide synthetases McyA and McyB described earlier for this strain. All structural microcystin variants produced by this strain were shown to inhibit protein phosphatase 1 in the nanomolar range.
\end{abstract}

Keywords Planktothrix $\cdot$ Cyanobacteria $\cdot$ Microcystins $\cdot$ Protein phosphatase inhibition

Among toxins produced by cyanobacteria in freshwater and estuarine systems, the microcystins (MCs) are the most frequent. MCs are cyclic heptapeptides. The most common core structure of these compounds is cyclo(-D-Ala ${ }^{1}-\mathrm{L}-\mathrm{X}^{2}$-DMeAsp ${ }^{3}-\mathrm{L}-\mathrm{Z}^{4}-\mathrm{Adda}^{5}-\mathrm{D}-\mathrm{Glu}^{6}-\mathrm{Mdha}^{7}$ ), where $\mathrm{X}$ and $\mathrm{Z}$ are

Electronic supplementary material The online version of this article (doi:10.1007/s13659-013-0001-3) contains supplementary material, which is available to authorized users.

T. H. J. Niedermeyer

Cyano Biotech GmbH, Magnusstr. 11, 12489 Berlin, Germany

T. H. J. Niedermeyer $(\square)$

Interfaculty Institute for Microbiology and Infection Medicine

Tübingen, Eberhard Karls University Tübingen,

Auf der Morgenstelle 28, 72076 Tübingen, Germany

e-mail: timo.niedermeyer@uni-tuebingen.de

P. Schmieder

Leibniz Institut für Molekulare Pharmakologie,

Robert-Rössle-Str. 10, 13125 Berlin, Germany

R. Kurmayer

Research Institute for Limnology, University of Innsbruck,

Mondseestrasse 9, 5310 Mondsee, Austria variable L-amino acids, D-MeAsp is D-erythro- $B$-iso-aspartic acid, Adda is $(2 S, 3 S, 8 S, 9 S)$-3-amino-9-methoxy-2,6,8trimethyl-10-phenyldeca-4,6-dienoic acid, and Mdha is $\mathrm{N}$ methyl-dehydroalanine [1]. More than 90 different natural MC congeners containing different amino acids especially at the variable positions 2 and 4 , but also at the other positions $1,3,5,6$, and 7 , have been described from both field and isolated strain samples [2, 3]. The most common variants (MC-RR, MC-YR, and MC-LR) feature either Arg, Tyr, or Leu in position 2 of the molecule, while Arg is predominant at position 4. Planktothrix strain No80 does not produce these common MC-variants, but rather the homotyrosine (Hty) containing congeners $\left[\mathrm{Asp}^{3},(E)\right.$ $\left.\mathrm{Dhb}^{7}\right] \mathrm{MC}-\mathrm{HtyY}$ and $\left[\mathrm{Asp}^{3},(E)-\mathrm{Dhb}^{7}\right] \mathrm{MC}-\mathrm{HtyHty}$ instead [4]. Notably, the genotypes that are able to synthesize these MC variants were only found in one habitat, and it was concluded that relaxed selection constrains paired with spatial isolation led to the appearance of this unique MC producer $[5,6]$. Since this strain also produces several minor MC structural variants in addition to the most dominant compounds [4], we were interested in their structural elucidation. Thus three compounds featuring the typical UV spectra of MCs containing Tyr or Trp have 
been isolated (1-3), and their structures have been elucidated. As it is known that MCs are potent inhibitors of protein serine/threonine phosphatases (PP) 1 and PP2A [7], the PP inhibitory activity of all the structural variants has been tested using MC-LR as reference compound.

\section{Results and Discussion}

Planktothrix rubescens strain No80 was grown in laboratory culture, and the dried cell biomass was extracted using aqueous methanol. Compounds (1-3) were isolated after fractionation of the crude extract on $\mathrm{C}_{18}$ solid-phase extraction cartridges followed by semi-preparative HPLC. The three compounds were obtained as amorphous white powders.

Tandem MS data confirmed that the compounds were $\mathrm{MC}$ variants, as for all three substances significant peaks at $m / z 375.19\left(\mathrm{z}_{3[711][5-7]}-\mathrm{C}_{9} \mathrm{H}_{10} \mathrm{O}\right.$ ion $)$ as well as fragments at $m / z, 135$ and the corresponding $\left[\mathrm{M}-\mathrm{C}_{9} \mathrm{H}_{10} \mathrm{O}\right]^{+}$fragments could be observed, ions characteristic for MCs containing the Adda substructure [8-10]. To facilitate structure elucidation, a Python script (see ESM) has been written to calculate molecular masses of possible MC variants based upon the residues found in microcystins isolated to date, taking into account monomers commonly observed for MCs from Planktothrix and Oscillatoria (e.g. Ala at position 1, Asp at position 3 of the MCs found in these genera) as well as the predicted amino acid substrate activation selectivities of the non-ribosomal peptide synthetase McyA found in P. rubescens strain No80 (Dhb at position 7) [4]. The script output gave indications which MC structures might match with the observed molecular masses of the three compounds.

HRMS data for compound 1 were consistent with a molecular formula of $\mathrm{C}_{51} \mathrm{H}_{69} \mathrm{~N}_{7} \mathrm{O}_{13}$ (found $\mathrm{m} / \mathrm{z}$ 988.5052, calcd. 988.5026 for $\left.[\mathrm{M}+\mathrm{H}]^{+}, \Delta 2.6 \mathrm{ppm}\right)$. The ${ }^{1} \mathrm{H}$ NMR spectrum of 1 in $d_{6}$-DMSO showed close similarities to those of other MCs isolated from Planktothrix [4]. The $\mathrm{NH}-\mathrm{CH}_{\alpha}$ cross peaks in the TOCSY spectrum served as the basis for the identification of the individual spin systems, and in conjunction with HMQC and HMBC data, the seven monomers in $\mathbf{1}$ could unambiguously be identified as Ala, Leu, Asp, Tyr, Adda, Glu, and 2-amino-2-butenoic acid (Dhb) (Table 1). As for the other MCs isolated from this strain [4], ROESY data supported the conventional all-E configurations of the Adda double bonds. The presence of the Dhb residue was revealed by a methyl doublet and an olefinic proton quartet resonating at $\delta 1.87$ and at $\delta 5.61$, typical for $(E)$-Dhb [4]. Leu and Tyr are the variable amino acids incorporated into positions 2 and 4 of this MC congener. The location of these two amino acids was established on the basis of ROESY NMR and tandem MS data.
Various ROESY correlations between Ala and Leu protons were detected. Furthermore, fragments at $\mathrm{m} / \mathrm{z}, 157$ and 185 observed in the tandem mass spectrum of $\mathbf{1}$ confirmed the direct proximity of Ala and Leu (a- and b-ions of the fragment Ala-Leu), proving that Leu is located at position 2 of this MC. ROESY correlations between Adda protons and Tyr protons support the close proximity of these two monomers, thus Tyr is situated at position 4. In addition to several ROESY correlations as indicated in Table 1, the postulated sequence of $\mathbf{1}$ was completely confirmed with high confidence by tandem MS. Using the software mMass to assign the peaks observed in the IT-TOF tandem mass spectrum [10], all signals could be assigned within a mass accuracy of $0.01 \mathrm{Da}$ (for more information see ESM). The structure of $\mathbf{1}$ could thus be determined as $\left[\mathrm{Asp}^{3},(E)\right.$ $\mathrm{Dhb}^{7} \mathrm{JMC}-\mathrm{LY}$. This compound has been tentatively reported from Planktothrix before, based on HPLC-MS ${ }^{2}$ analyses and thiol derivatization [11].

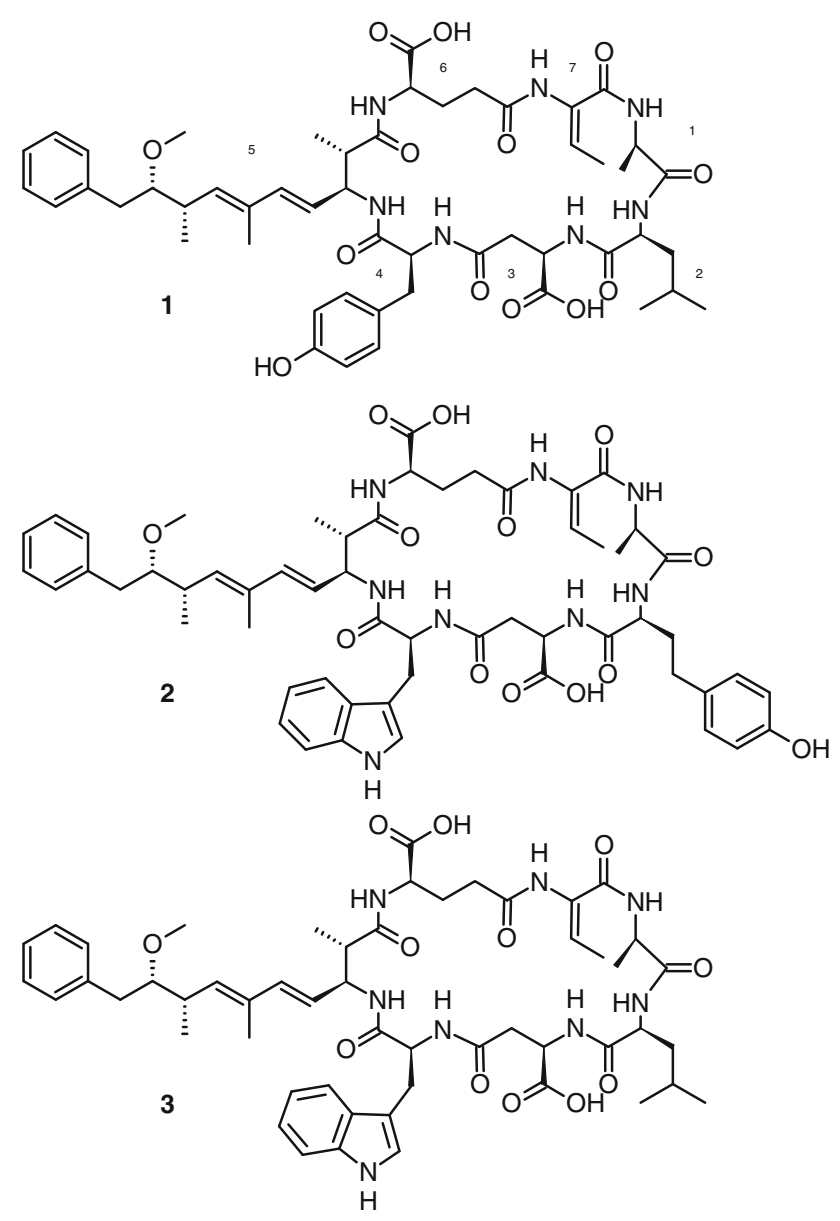

HRMS data of compound 2 supported the molecular formula $\mathrm{C}_{57} \mathrm{H}_{70} \mathrm{~N}_{8} \mathrm{O}_{13}$ (found $\mathrm{m} / z$ 1075.5133, calcd. 1075.5135 for $\left.[\mathrm{M}+\mathrm{H}]^{+}, \Delta 0.2 \mathrm{ppm}\right)$. Its ${ }^{1} \mathrm{H}$ NMR spectrum resembled that of $\mathbf{1}$ concerning the prominent signals of Adda and Dhb. However, there were also striking 
Table $1{ }^{1} \mathrm{H}\left(750 \mathrm{MHz}, d_{6}\right.$-DMSO) and ${ }^{13} \mathrm{C}$ NMR Spectroscopic Assignments for $\left[\mathrm{Asp}^{3},(E)-\mathrm{Dhb}^{7}\right] \mathrm{MC}-\mathrm{LY}(\mathbf{1})$

\begin{tabular}{|c|c|c|c|c|c|}
\hline Unit & Position & $\delta_{\mathrm{C}}$ & $\delta_{\mathrm{H}}(J$ in $\mathrm{Hz})$ & $\mathrm{HMBC}^{\mathrm{a}}$ & ROESY \\
\hline \multirow[t]{20}{*}{ Adda } & 1 & 173.7 & & & \\
\hline & 2 & 41.9 & $3.07, \mathrm{~m}$ & & 3 \\
\hline & 3 & 54.4 & $4.29, \mathrm{~m}$ & 11 & $2,5,11, \mathrm{NH}$ \\
\hline & 4 & 126.5 & $5.32, \mathrm{~m}$ & & $3,5,7,11,12, \mathrm{NH}, \mathrm{Tyr}-5 / 9$, Tyr-6/8 \\
\hline & 5 & 135.5 & $6.13, \mathrm{~d}(15.3)$ & $3,7,12$ & $3,4,7,11,12,16 / 20,17 / 19$, Tyr-5/9, Tyr-6/8 \\
\hline & 6 & 131.6 & & & \\
\hline & 7 & 134.8 & $5.47, \mathrm{~d}(9.2)$ & $5,12,13$ & $4,5,8,9,10,13,14,16 / 20,17 / 19$, Tyr-5/9, Tyr-6/8 \\
\hline & 8 & 35.1 & $2.57, \mathrm{~m}$ & $6,7,9,13$ & $7,9,10 \mathrm{a} / \mathrm{b}, 12,13,14$ \\
\hline & 9 & 85.5 & $3.27, \mathrm{~m}$ & $7,8,10,13,14,15$ & $7,8,10,13$ \\
\hline & $10 \mathrm{a}$ & 36.7 & 2.76, dd $(13.7,4.6)$ & $8,9,15,16 / 20$ & $7,8,9,13,14,16 / 20$ \\
\hline & $10 \mathrm{~b}$ & & 2.69, dd $(13.7,6.9)$ & $8,9,15,16 / 20$ & $7,8,9,13,14,16 / 20$ \\
\hline & 11 & 15.6 & 0.88, br. d (3.8) & 1,3 & $3,4,5$ \\
\hline & 12 & 12.2 & $1.57, \mathrm{~s}$ & $5,6,7$ & $4,5,8,14$ \\
\hline & 13 & 15.7 & $0.99, \mathrm{~d}(6.9)$ & $7,8,9$ & $7,8,10 \mathrm{a} / \mathrm{b}, 14$ \\
\hline & 14 & 57.0 & $3.20, \mathrm{~s}$ & 9 & $7,8,10 \mathrm{a} / \mathrm{b}, 12,13,16 / 20$ \\
\hline & 15 & 138.9 & & & \\
\hline & $16 / 20$ & 129.0 & $7.20, \mathrm{~m}$ & $10,15,16 / 20,17 / 19,18$ & $5,7,10 \mathrm{a} / \mathrm{b}, 14$ \\
\hline & $17 / 19$ & 127.8 & $7.27, \mathrm{~m}$ & $15,16 / 20,17 / 19,18$ & $5,7,10 \mathrm{a} / \mathrm{b}, 14$ \\
\hline & 18 & 125.5 & $7.17, \mathrm{~m}$ & $15,16 / 20,17 / 19$ & \\
\hline & $\mathrm{NH}$ & & 8.19, br. s & & 3,4, Tyr-2 \\
\hline \multirow[t]{8}{*}{ Glu } & 1 & 171.6 & & & \\
\hline & 2 & 51.6 & $4.25, \mathrm{~m}$ & & $3 a, 4 b$ \\
\hline & $3 a$ & 25.2 & $1.91, \mathrm{~m}$ & 1,5 & $3 \mathrm{a}$ \\
\hline & $3 b$ & & $1.75, \mathrm{~m}$ & 1,5 & $2,3 b, 4 b$ \\
\hline & $4 \mathrm{a}$ & 32.0 & $2.44, \mathrm{~m}$ & 5 & 2, 3a, Dhb-NH \\
\hline & $4 b$ & & $2.04, \mathrm{~m}$ & & Dhb-NH \\
\hline & 5 & 170.9 & & & \\
\hline & $\mathrm{NH}$ & & 9.25, br. s & & \\
\hline \multirow[t]{5}{*}{ Dhb } & 1 & 162.6 & & & \\
\hline & 2 & 130.6 & & & \\
\hline & 3 & 120.4 & $5.61, \mathrm{q}(6.9)$ & $1,2,4$ & 4, NH, Tyr-6/8 \\
\hline & 4 & 12.7 & $1.87, \mathrm{~d}(6.9)$ & $1,2,3$ & 3, Tyr-6/8 \\
\hline & $\mathrm{NH}$ & & 10.07, br. s & & 3, 4, Tyr-2, Glu-4a/4b \\
\hline \multirow[t]{4}{*}{ Ala } & 1 & 172.2 & & & \\
\hline & 2 & 46.2 & $4.37, \mathrm{~m}$ & Dhb-1, 1, 3 & 3, NH, Leu-5, Leu-6, Leu-NH \\
\hline & 3 & 15.9 & 0.69, br. d & & 2, NH, Tyr-5/9, Tyr-6/8, Tyr-OH \\
\hline & $\mathrm{NH}$ & & 7.06, br. s & & 2,3, Leu-NH \\
\hline \multirow[t]{8}{*}{ Leu } & 1 & 170.6 & & & \\
\hline & 2 & 53.4 & $3.89, \mathrm{~m}$ & & $3 b, 4,6, \mathrm{NH}$ \\
\hline & $3 a$ & 38.4 & $1.76, \mathrm{~m}$ & & $2,3 \mathrm{a}, 4, \mathrm{NH}$ \\
\hline & $3 b$ & & $1.42, \mathrm{~m}$ & 1 & $3 b, \mathrm{NH}$ \\
\hline & 4 & 23.8 & $1.64, \mathrm{~m}$ & & $2,3 b, \mathrm{NH}$ \\
\hline & 5 & 22.7 & $0.84, \mathrm{~d}(6.1)$ & $3,4,6$ & Ala-2 \\
\hline & 6 & 20.7 & $0.78, \mathrm{~d}(6.1)$ & $3,4,5$ & $2, \mathrm{NH}$, Ala-2 \\
\hline & NH & & 7.98, br. s & & 2, 3a/b, 4, 6, Ala-2, Ala-NH \\
\hline \multirow[t]{3}{*}{ Asp } & 1 & 170.0 & & & \\
\hline & 2 & 50.2 & $4.16, \mathrm{~m}$ & & \\
\hline & $3 a$ & 37.6 & $2.75, \mathrm{~m}$ & & $3 a$ \\
\hline
\end{tabular}


Table 1 continued

\begin{tabular}{|c|c|c|c|c|c|}
\hline Unit & Position & $\delta_{\mathrm{C}}$ & $\delta_{\mathrm{H}}(J$ in $\mathrm{Hz})$ & $\mathrm{HMBC}^{\mathrm{a}}$ & ROESY \\
\hline & $3 b$ & & $1.52, \mathrm{~m}$ & & 3b, Tyr-NH \\
\hline & 4 & n.o. & & & \\
\hline & $\mathrm{NH}$ & & 7.78, br. s & & \\
\hline \multirow[t]{10}{*}{ Tyr } & 1 & 173.0 & & & \\
\hline & 2 & 52.8 & $4.69, \mathrm{~m}$ & & Adda-NH, 3a/b, 5/9, NH \\
\hline & $3 a$ & 35.4 & $3.30, \mathrm{~m}$ & 1 & $2,3 \mathrm{a}, 5 / 9, \mathrm{NH}$ \\
\hline & $3 b$ & & $2.26, \mathrm{~m}$ & & $2,3 b, 5 / 9$ \\
\hline & 4 & 129.2 & & & \\
\hline & $5 / 9$ & 128.3 & $6.92, \mathrm{~d}(7.6)$ & $3,4,5 / 9,6 / 8,7$ & $2,3 \mathrm{a} / \mathrm{b}$, Ala-3 \\
\hline & $6 / 8$ & 114.3 & $6.43, \mathrm{~d}(7.6)$ & $5 / 8,7$ & Ala-3 \\
\hline & 7 & 155.0 & & & \\
\hline & $\mathrm{NH}$ & & 8.52 , br. s & & $2,3 b$, Asp-3a \\
\hline & $\mathrm{OH}$ & & 8.99 , br. s & & 6/8, Ala-3 \\
\hline
\end{tabular}

${ }^{13} \mathrm{C}$ chemical shifts obtained from HMQC and HMBC spectra $\left({ }^{1} \mathrm{H}\right.$ frequency $600 \mathrm{MHz}$, in $d_{6}$-DMSO)

n.o. not observed

${ }^{a} \mathrm{HMBC}$ correlations are stated from proton to the indicated carbon

Table $2{ }^{1} \mathrm{H}\left(750 \mathrm{MHz}, d_{6}\right.$-DMSO) and ${ }^{13} \mathrm{C}$ NMR Spectroscopic Assignments for [Asp ${ }^{3},(E)$-Dhb $\left.{ }^{7}\right] \mathrm{MC}-\mathrm{HtyW}(\mathbf{2})$

\begin{tabular}{|c|c|c|c|c|c|}
\hline Unit & Position & $\delta_{\mathrm{C}}$ & $\delta_{\mathrm{H}}(J$ in $\mathrm{Hz})$ & $\mathrm{HMBC}^{\mathrm{a}}$ & ROESY \\
\hline \multirow[t]{20}{*}{ Adda } & 1 & 174.7 & & & \\
\hline & 2 & 42.1 & $3.03, \mathrm{~m}$ & 4 & 11, Trp-3b \\
\hline & 3 & 53.9 & $4.35, \mathrm{~m}$ & 1 & $5,11, \mathrm{NH}$ \\
\hline & 4 & 126.1 & $5.35, \mathrm{~m}$ & & $5,11,12, \mathrm{NH}$ \\
\hline & 5 & 135.1 & $6.16, \mathrm{~d}(15.3)$ & $3,6,12,7$ & $3,4,7,11$ \\
\hline & 6 & 131.8 & & & \\
\hline & 7 & 134.5 & $5.50, \mathrm{~d}(9.2)$ & 5,12 & $5,8,9,10 \mathrm{a} / \mathrm{b}, 13$ \\
\hline & 8 & 35.0 & $2.59, \mathrm{~m}$ & $6,7,9,13$ & $7,9,12,13,14$ \\
\hline & 9 & 85.6 & $3.28, \mathrm{~m}$ & $7,8,11,12,14$ & $7,8,10 \mathrm{a} / \mathrm{b}, 13$ \\
\hline & $10 \mathrm{a}$ & 36.5 & 2.76 , dd $(13.7,4.6)$ & $8,9,15,16 / 20$ & $7,9,12,13,16 / 20$ \\
\hline & $10 \mathrm{~b}$ & & $2.70, \mathrm{dd}(13.7,7.6)$ & $8,9,15,16 / 20$ & $7,9,13,16 / 20$ \\
\hline & 11 & 15.6 & $0.90, \mathrm{~d}(4.6)$ & $1,2,3$ & $2,3,4,5$ \\
\hline & 12 & 12.0 & $1.58, \mathrm{~s}$ & $5,6,7$ & $4,8,10 \mathrm{a}, 13$ \\
\hline & 13 & 15.5 & $1.00, \mathrm{~d}(6.1)$ & $7,8,9$ & $7,8,9,10 \mathrm{a} / \mathrm{b}, 12,14$ \\
\hline & 14 & 56.9 & $3.21, \mathrm{~s}$ & 9 & 8,13 \\
\hline & 15 & 138.9 & & & \\
\hline & $16 / 20$ & 128.9 & $7.21, \mathrm{~m}$ & $15,16 / 20,17 / 19,20$ & $10 \mathrm{a} / \mathrm{b}$ \\
\hline & $17 / 19$ & 127.7 & $7.27, \mathrm{~m}$ & $15,16 / 20,17 / 19,18$ & \\
\hline & 18 & 125.3 & $7.18, \mathrm{~m}$ & $15,16 / 20,17 / 19$ & \\
\hline & $\mathrm{NH}$ & & 8.15 , br. s & & $3,4, \operatorname{Trp}-2$ \\
\hline \multirow[t]{8}{*}{ Glu } & 1 & 171.2 & & & \\
\hline & 2 & 49.8 & $4.24, \mathrm{~m}$ & 4 & \\
\hline & $3 a$ & 24.1 & $1.91, \mathrm{~m}$ & 1 & \\
\hline & $3 b$ & & $1.74, \mathrm{~m}$ & 5 & \\
\hline & $4 a$ & 31.5 & $2.41, \mathrm{~m}$ & 5 & \\
\hline & $4 b$ & & $2.06, \mathrm{~m}$ & & Dhb-NH \\
\hline & 5 & 171.7 & & & \\
\hline & $\mathrm{NH}$ & & 9.24 , br. s & & \\
\hline
\end{tabular}


Table 2 continued

\begin{tabular}{|c|c|c|c|c|c|}
\hline Unit & Position & $\delta_{\mathrm{C}}$ & $\delta_{\mathrm{H}}(J$ in $\mathrm{Hz})$ & $\mathrm{HMBC}^{\mathrm{a}}$ & ROESY \\
\hline \multirow[t]{5}{*}{ Dhb } & 1 & 162.7 & & & \\
\hline & 2 & 130.4 & & & \\
\hline & 3 & 120.9 & $5.62, \mathrm{q}(6.1)$ & $1,2,4$ & $4, \mathrm{NH}$ \\
\hline & 4 & 12.6 & $1.86, \mathrm{~d}(6.1)$ & 2,3 & $\begin{array}{l}\text { 3, NH, Trp-5, Hty-2, } \\
\text { Hty-3b }\end{array}$ \\
\hline & $\mathrm{NH}$ & & 10.00 , br. s & & 3, 4, Glu-4b \\
\hline \multirow[t]{4}{*}{ Ala } & 1 & n.o. & & & \\
\hline & 2 & 45.9 & $4.19, \mathrm{~m}$ & & Hty-NH \\
\hline & 3 & 15.3 & 0.43 , br. d & & \\
\hline & $\mathrm{NH}$ & & 6.95 , br. s & & \\
\hline \multirow[t]{12}{*}{ Hty } & 1 & n.o. & & & \\
\hline & 2 & 53.9 & $3.76, \mathrm{~m}$ & & $3 b, 4 b, N H, D h b-4$ \\
\hline & $3 \mathrm{a}$ & 32.1 & $1.99, \mathrm{~m}$ & 5 & NH \\
\hline & $3 b$ & & $1.83, \mathrm{~m}$ & & $2,7 / 9$, Dhb-4 \\
\hline & $4 \mathrm{a}$ & 30.2 & $2.55, \mathrm{~m}$ & $6 / 10$ & $4 b, \mathrm{NH}$ \\
\hline & $4 \mathrm{~b}$ & & $2.35, \mathrm{~m}$ & & $2,4 a, 6 / 10, \mathrm{NH}$ \\
\hline & 5 & 129.4 & & & \\
\hline & $6 / 10$ & 129.0 & $6.93, \mathrm{~d}(7.6)$ & $4,6 / 10,8$ & $4 b, 7 / 9$ \\
\hline & $7 / 9$ & 114.5 & $6.61, \mathrm{~d}(7.6)$ & $6 / 10,7 / 9,8$ & $3 b, 6 / 10, \operatorname{Trp}-10$ \\
\hline & 8 & 155.0 & & & \\
\hline & $\mathrm{NH}$ & & 8.06 , br. s & & $2,3 a, 4 a / b$, Ala-2 \\
\hline & $\mathrm{OH}$ & & 9.06 , br. s & & \\
\hline \multirow[t]{6}{*}{ Asp } & 1 & 174.3 & & & \\
\hline & 2 & 51.8 & $4.23, \mathrm{~m}$ & & \\
\hline & $3 \mathrm{a}$ & 37.7 & $2.80, \mathrm{~m}$ & 1 & $3 b$ \\
\hline & $3 b$ & & $1.48, \mathrm{~m}$ & & $3 \mathrm{a}$ \\
\hline & 4 & n.o. & & & \\
\hline & $\mathrm{NH}$ & & 7.77, br. s & & \\
\hline \multirow[t]{14}{*}{ Trp } & 1 & 173.2 & & & \\
\hline & 2 & 51.2 & $4.78, \mathrm{~m}$ & 3 & 3a, 7, Adda-NH \\
\hline & $3 a$ & 26.4 & $3.51, \mathrm{~m}$ & & $2,3 b$ \\
\hline & $3 b$ & & $2.59, \mathrm{~m}$ & 1 & 3a, $\mathrm{NH}_{\text {amide }}$, Adda-2 \\
\hline & 4 & 110.9 & & & \\
\hline & 5 & 118.0 & $6.79, \mathrm{~m}$ & 4,6 & 7, Dhb-4 \\
\hline & 6 & 126.7 & & & \\
\hline & 7 & 117.8 & $7.54, \mathrm{~d}(7.6)$ & $4,6,9,11$ & $2,5,8$ \\
\hline & 8 & 122.3 & $6.94, \mathrm{~m}$ & 6,10 & 7 \\
\hline & 9 & 120.2 & $6.96, \mathrm{~m}$ & 7,11 & 10 \\
\hline & 10 & 110.7 & $7.24, \mathrm{~d}(7.6)$ & 6,7 & 9, Hty-7/9 \\
\hline & 11 & 136.0 & & & \\
\hline & $\mathrm{NH}_{\text {amide }}$ & & 8.58, br. s & & $2,3 b$ \\
\hline & $\mathrm{NH}_{\text {indole }}$ & & 10.60 , br. s & 6,10 & \\
\hline
\end{tabular}

${ }^{13} \mathrm{C}$ chemical shifts obtained from HMQC and HMBC spectra $\left({ }^{1} \mathrm{H}\right.$ frequency $600 \mathrm{MHz}$, in $\mathrm{d}_{6}$-DMSO)

n.o. not observed

${ }^{\text {a }} \mathrm{HMBC}$ correlations are stated from proton to the indicated carbon

differences observed: While the Leu methyl group resonances were missing, an additional $\mathrm{NH}$ proton at very low field $(10.60 \mathrm{ppm})$ as well as additional signals in the aromatic region indicated the presence of Trp and the absence of Leu. Closer examination of the TOCSY and HMBC spectra, however, revealed that Hty, rather than the 
Table 3 Selected ${ }^{1} \mathrm{H}$ NMR Spectroscopic Assignments $(750 \mathrm{MHz}$, $d_{6}$-DMSO) for $\left[\mathrm{Asp}^{3},(E)-\mathrm{Dhb}^{7}\right] \mathrm{MC}-\mathrm{LW}(3)$

\begin{tabular}{|c|c|c|c|}
\hline Monomer & Position & $\delta_{\mathrm{H}}(J$ in $\mathrm{Hz})$ & COSY \\
\hline \multirow[t]{17}{*}{ Adda } & 2 & $3.00, \mathrm{~m}$ & 3,11 \\
\hline & 3 & $4.34, \mathrm{~m}$ & 2,4 \\
\hline & 4 & $5.32, \mathrm{~m}$ & 3,5 \\
\hline & 5 & $6.17, \mathrm{~d}(15.3)$ & \\
\hline & 7 & $5.51, \mathrm{~d}(9.2)$ & 8,12 \\
\hline & 8 & $2.59, \mathrm{~m}$ & $7,9,13$ \\
\hline & 9 & $3.27, \mathrm{~m}$ & $8,10 \mathrm{a} / \mathrm{b}$ \\
\hline & $10 \mathrm{a}$ & $2.76, \mathrm{~m}$ & 9 \\
\hline & $10 \mathrm{~b}$ & $2.69, \mathrm{~m}$ & 9 \\
\hline & 11 & $0.90, \mathrm{~d}(4.6)$ & 2 \\
\hline & 12 & $1.58, \mathrm{~s}$ & 7 \\
\hline & 13 & $1.00, \mathrm{~d}(6.9)$ & 8 \\
\hline & 14 & $3.20, \mathrm{~s}$ & \\
\hline & $16 / 20$ & $7.21, \mathrm{~m}$ & $17 / 19$ \\
\hline & $17 / 19$ & $7.27, \mathrm{~m}$ & $16 / 20,18$ \\
\hline & 18 & $7.19, \mathrm{~m}$ & $17 / 19$ \\
\hline & $\mathrm{NH}$ & 8.19 , br. & \\
\hline \multirow[t]{3}{*}{ Dhb } & 3 & $5.61, \mathrm{~m}$ & 4 \\
\hline & 4 & $1.88, \mathrm{~m}$ & 3 \\
\hline & $\mathrm{NH}$ & 9.95 , br. & \\
\hline \multirow[t]{7}{*}{ Leu } & 2 & $3.88, \mathrm{~m}$ & $3 \mathrm{a} / \mathrm{b}, \mathrm{NH}$ \\
\hline & $3 a$ & $1.77, \mathrm{~m}$ & $2,3 b$ \\
\hline & $3 b$ & $1.39, \mathrm{~m}$ & $2,3 a, 4$ \\
\hline & 4 & $1.63, \mathrm{~m}$ & $3 b, 5,6$ \\
\hline & 5 & $0.82, \mathrm{~m}$ & 4 \\
\hline & 6 & $0.75, \mathrm{~d}(6.1)$ & 4 \\
\hline & $\mathrm{NH}$ & 7.92, br. & 2 \\
\hline \multirow[t]{10}{*}{ Trp } & 2 & $4.80, \mathrm{~m}$ & $3 \mathrm{~b}, \mathrm{NH}_{\text {amide }}$ \\
\hline & $3 a$ & $3.48, \mathrm{~m}$ & $3 b$ \\
\hline & $3 b$ & $2.62, \mathrm{~m}$ & $2,3 \mathrm{a}$ \\
\hline & 5 & $6.77, \mathrm{~m}$ & 7,8 \\
\hline & 7 & $7.54, \mathrm{~d}(7.6)$ & 5 \\
\hline & 8 & $6.94, \mathrm{~m}$ & 5 \\
\hline & 9 & $6.96, \mathrm{~m}$ & 10 \\
\hline & 10 & $7.23, \mathrm{~d}(7.6)$ & 9 \\
\hline & $\mathrm{NH}_{\text {amide }}$ & 8.59 , br. & 2 \\
\hline & $\mathrm{NH}_{\text {indole }}$ & 10.59 , br. & \\
\hline
\end{tabular}

Tyr found in 1, was present in this MC congener (NMR data see Table 2). To establish the sequence of $\mathbf{2}$, again ROESY and tandem MS were used. ROESY data clearly showed the proximity of Adda and Trp, and of Ala and Hty. ROESY data also showed a rather intriguing conformation of 2. Both Trp and Hty showed ROESY correlations with Ala, implying that these flexible side chains seem to cluster in this part of the molecule. As with $\mathbf{1}$, the sequence of $\mathbf{2}$ has been confirmed using mMass. Here, an a-ion at $m / z 221$ confirmed the sequence Ala-Hty, and most of the peaks of the tandem mass spectrum could be annotated based on the postulated sequence. Taking all data into account, 2 was identified as $\left[\mathrm{Asp}^{3},(E)-\mathrm{Dhb}^{7}\right] \mathrm{MC}-\mathrm{HtyW}$. The presence of both Hty and Trp make this MC congener one of those with the highest molecular weight.

HRMS of 3 showed a quasi-molecular ion at $m / z$ 1011.5172, corresponding to the molecular formula $\mathrm{C}_{53} \mathrm{H}_{70} \mathrm{~N}_{8} \mathrm{O}_{12}$ (calcd. 1011.5186 for $[\mathrm{M}+\mathrm{H}]^{+}, \Delta-1.4 \mathrm{ppm}$ ). The ${ }^{1} \mathrm{H}$ NMR spectrum showed similarities with the spectra of both 1 and 2: The typical $\mathrm{NH}$ and aromatic signals of a Trp were observed as in $\mathbf{2}$, and methyl resonances as in $\mathbf{1}$ indicated the presence of Leu. However, the aromatic signals of the Tyr/ Hty moiety were missing. COSY correlations confirmed the presence of Leu and Trp as well as of Adda and Dhb (Table 3). As only small amounts of $\mathbf{3}$ could be isolated, the carbon chemical shifts could not be deduced from HSQC or HMBC spectra. Sequence elucidation was thus based on tandem MS data, a common approach for MCs $[9,12,13]$. Again, the a- and b-ion fragments for Ala-Leu could be observed, showing that Leu was present at position 2 of this MC. The theoretical fragments calculated for the postulated sequence match well with the observed fragments, and the observed b-ions can be interlaced to cover the complete postulated sequence (Fig. 1). Furthermore, the ${ }^{1} \mathrm{H}$ chemical shifts of Trp and Leu in $\mathbf{3}$ were almost identical with those of the respective monomers in $\mathbf{1}$ and $\mathbf{2}$, supporting the assumption that these monomers were located in the same positions as Leu in $\mathbf{1}$ and Trp in $\mathbf{2}$. The structure of $\mathbf{3}$ can thus be postulated to be $\left[\mathrm{Asp}^{3},(E)-\mathrm{Dhb}^{7}\right] \mathrm{MC}-\mathrm{LW}$.

As has been shown previously [14], the adenylation domains (A-domains) encoded by the $m c y \mathrm{BA} 1$ and $m c y \mathrm{CA}$ genes that are part of the $\mathrm{MC}(m c y)$ synthetase gene cluster are responsible for the recognition and activation of amino acids at the variable positions 2 and 4, resp. Comparing a larger number of strains, within mcyBA1 an exclusive correlation between a certain mcyBA1 genotype and the occurrence of Hty or Leu in position 2 of the molecule with simultaneous absence of Arg at this position was recognized [6]. The mcyBA1 genotype of Planktothrix strain No80 was shown to fit exactly to this genotype [4]. Surprisingly, $m c y C A$ showed much less nucleotide variation compared to $m c y \mathrm{BA} 1$, and only a few point mutations could be related to the presence of Tyr/Hty in position 4 of the molecule [4]. It is interesting to note that the same McyCA domain, which has no precedent in the NRPS database [15, 16], apparently is able to activate an additional aromatic amino acid substrate, Trp, as observed in compounds $\mathbf{2}$ and $\mathbf{3}$.

MC biosynthesis in Planktothrix has been studied in great detail, and it is known that different MC congeners synthesized by an individual strain are products of the same MC synthetase [17]. Amino acid variability in MC congeners is due to multispecific domains that allow for 


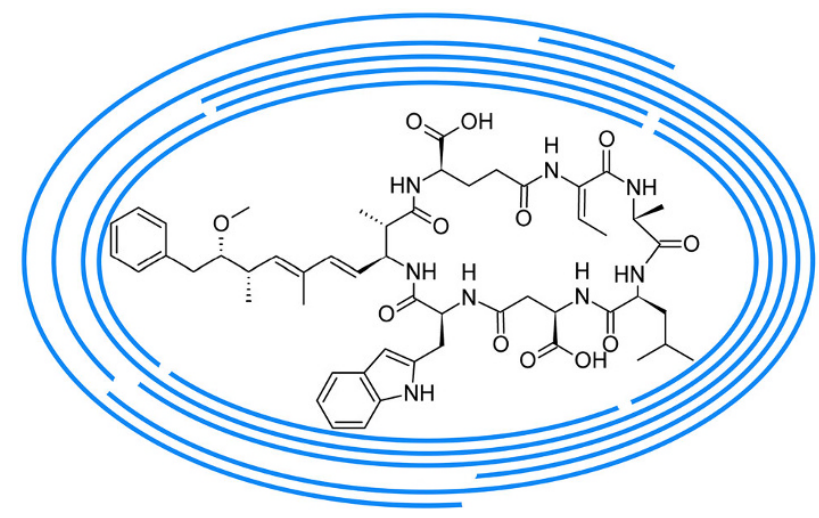

Fig. 1 Interlaced b-ions observed in the tandem MS spectrum of 3 (for details on the observed fragments see ESM)

Table 4 PP-1 inhibitory activity of five [D-Asp $\left.{ }^{3}, \mathrm{Dhb}^{7}\right]$-MC structural variants produced by Planktothrix strain No80 and MC-LR

\begin{tabular}{llll}
\hline & $\begin{array}{l}\mathrm{IC}_{50} \\
(\mathrm{nM})\end{array}$ & $\begin{array}{l}\text { Fitting } \\
\text { error (\%) }\end{array}$ & $R^{2}$ of fit \\
\hline MC-LR & 2.0 & 16.5 & 0.9923 \\
{$\left[\mathrm{Asp}^{3},(E)-\mathrm{Dhb}^{7}\right]$ MC-HtyY } & 2.9 & 16.0 & 0.9867 \\
{$\left[\mathrm{Asp}^{3},(E)-\mathrm{Dhb}^{7}\right]$ MC-HtyHty } & 3.2 & 11.1 & 0.9963 \\
{$\left[\mathrm{Asp}^{3},(E)-\mathrm{Dhb}^{7}\right] \mathrm{MC}-\mathrm{LY}(\mathbf{1})$} & 3.8 & 13.6 & 0.9953 \\
{$\left[\mathrm{Asp}^{3},(E)-\mathrm{Dhb}^{7}\right] \mathrm{MC}-\mathrm{HtyW}(\mathbf{2})$} & 5.0 & 10.1 & 0.9970 \\
{$\left[\mathrm{Asp}^{3},(E)-\mathrm{Dhb}^{7}\right] \mathrm{MC}-\mathrm{LW}(\mathbf{3})$} & 5.4 & 15.2 & 0.9947 \\
\hline
\end{tabular}

incorporation of different amino acids rather than different biosynthesis enzymes [17]. For two MCs isolated from $P$. rubescens strain No80, [Asp $\left.{ }^{3},(E)-\mathrm{Dhb}^{7}\right] \mathrm{MC}-\mathrm{HtyH}$ ty and $\left[\mathrm{Asp}^{3},(E)-\mathrm{Dhb}^{7}\right] \mathrm{MC}-\mathrm{HtyY}$, the absolute configuration of the residues D-Ala, D-Glu, D-Asp, L-Tyr and L-Hty has been determined by chiral GC after hydrolysis and trifluoroacetylation [4]. Because all the MC variants found in this strain are synthesized by the same synthetase, it can safely be assumed that the amino acids in $\mathbf{1}, \mathbf{2}$, and $\mathbf{3}$ have the same configuration as those in the first two isolated MCs.

The protein phosphatase (PP) inhibition assay revealed that all MC structural variants inhibited PP-1 in the nanomolar range (Table 4). All $\mathrm{IC}_{50}$ estimates were comparable to the inhibitory activity of MC-LR, confirming that the residues in position 2, 3, 4, and 7 of the MCs have only little influence on PP-1 inhibition potency, which is mainly due to the Adda ${ }^{5}-\mathrm{Glu}^{6}$ substructure [18-21].

\section{Experimental Section}

\subsection{General Experimental Procedures}

Samples for NMR spectroscopy were dissolved in $600 \mu \mathrm{L}$ $d_{6}$-DMSO to yield concentrations of $1.7 \mathrm{mM}(\mathbf{1}), 1.1 \mathrm{mM}$
(2), and $0.5 \mathrm{mM}(3)$. NMR spectra were recorded at 600 or $750 \mathrm{MHz}\left({ }^{1} \mathrm{H}\right.$ frequency) on Bruker AV-III spectrometers using cryogenically cooled $5 \mathrm{~mm}$ TCI-triple resonance probes equipped with one-axis self-shielded gradients. All homonuclear two-dimensional spectra (DQF-COSY [22], TOCSY [23, 24], ROESY [25, 26] were recorded using $2,048 \times 512$ complex data points. DQF-COSYs and TOCSYs were recorded using 8 scans, the ROESY using 64 scans, the TOCSYs with a mixing time of $80 \mathrm{~ms}$, the ROESYs with a mixing time of $100 \mathrm{~ms}$. Low-power irradiation at the frequency of the water resonance was used to remove signals from residual water. Heteronuclear twodimensional ${ }^{13} \mathrm{C}$-HMQC [27] and the ${ }^{13} \mathrm{C}$-DEPT-HMQC [28] spectra were recorded using $512 \times 512$ complex data points using 96 scans, while the ${ }^{13} \mathrm{C}-\mathrm{HMQC}-\mathrm{TOCSY}$ [29] spectra were recorded with $512 \times 256$ complex data points using 96 scans and a mixing time of $80 \mathrm{~ms}$. All the above heteronuclear spectra were recorded using a BIRD pulse for suppression of protons bound to ${ }^{12} \mathrm{C}$ [30]. A gradientenhanced- ${ }^{13} \mathrm{C}-\mathrm{HMBC}$ [31] was recorded with $2048 \times 512$ complex data points using 160 scans. Spectra were referenced indirectly to tetramethylsilane via the residual signals of $d_{6}$-DMSO (2.50 ppm for ${ }^{1} \mathrm{H}, 39.5 \mathrm{ppm}$ for $\left.{ }^{13} \mathrm{C}\right) .{ }^{13} \mathrm{C}$ chemical shifts were extracted from the two-dimensional ${ }^{13} \mathrm{C}$-spectra. IT-TOF MS data have been acquired using an HPLC coupled to an IT-TOF mass spectrometer (Shimadzu Europe GmbH, Duisburg, Germany) with electrospray ionization in positive mode and were evaluated using the vendor's software LCMSSolution version 3.60.361 with Formula Predictor version 1.13. The compounds were separated on a Kinetex $\mathrm{C}_{18}$ column $(2.6 \mu \mathrm{m}, 100 \times 3 \mathrm{~mm}$, phenomenex, Torrance, USA) using a gradient ranging from 5 to $80 \% \mathrm{CH}_{3} \mathrm{CN}$ in water over $25 \mathrm{~min}(0.1 \%$ formic acid added as modifier). Precursor ions corresponding to $[\mathrm{M}+\mathrm{H}]^{+}$were isolated in the ion trap, fragmented by collision induced dissociation (CID) using argon as collision gas (collision energy set to $150 \%$, collision gas to $100 \%$, and $\mathrm{q}($ Frequency) to $45.0 \mathrm{kHz}$ ), and separated in the TOF analyzer. MS/MS scans were averaged and converted to the mzXML format using the vendor's software. For the calculation of sum formulae, the monoisotopic mass averaged from at least three scans has been used (resolution 10000, external calibration using sodium TFA ions clusters immediately prior to analysis). QTOF MS data were acquired using an ABSciex Qstar XL equipped with a nano electrospray source. Precursor ions were isolated with low quadrupole resolution. Fragmentation energies were set to automatic (rolling collision energy).

\subsection{Cyanobacterial Material}

Planktothrix rubescens strain No80 has been isolated from Lake Schwarzensee (Upper Austria) [5]. It was classified as 
P. rubescens on the basis of PCR analysis and sequencing of various marker genes [32], and has been deposited under this accession number in the culture collection of the Institute for Limnology in Mondsee, Austria. The strain was cultivated in BG11 medium [33] at $20{ }^{\circ} \mathrm{C}$ under continuous light $\left(60-80 \mu \mathrm{mol} \mathrm{m}^{-2} \mathrm{~s}^{-1}\right)$ in $20 \mathrm{~L}$ scale photobioreactors and harvested semi-continuously over a period of several weeks.

\subsection{Extraction and Isolation}

Cyanobacterial cells were harvested and lyophilized. $78.0 \mathrm{~g}$ dry biomass were suspended in $50 \% \mathrm{MeOH}(\mathrm{v} / \mathrm{v})$, treated with an ultrasonication rod (Bandelin, Berlin, Germany) and extracted on a shaker for $30 \mathrm{~min}$. After centrifugation the biomass was subsequently extracted using $80 \% \mathrm{MeOH}(\mathrm{v} / \mathrm{v})$. The extracts were combined and dried in vacuo, yielding $17.2 \mathrm{~g}$ of crude extract. $14 \mathrm{~g}$ of the crude extract were fractionated using a $\mathrm{C}_{18}$ cartridge (VersaPak, 40-75 $\mu \mathrm{m}, 40 \times 150 \mathrm{~mm}$ ) on a VersaFlash system (supelco, Bellefonte, USA). A step gradient of 20, 40, 60 and $80 \% \mathrm{MeOH}$ in water (v/v), each $700 \mathrm{~mL}$, has been used at a flow rate of $20 \mathrm{~mL} / \mathrm{min}$. The $60 \% \mathrm{MeOH}$ (v/v) fraction containing the MCs was dried in vacuo. After reconstitution, this fraction was subjected to semi-preparative HPLC on a SymmetryShield RP18, $5 \mu \mathrm{m}$, $10 \times 250 \mathrm{~mm}$ column (Waters, Milford, USA) using a linear step gradient of aqueous $\mathrm{CH}_{3} \mathrm{CN}$ (with $0.025 \% \mathrm{v} / \mathrm{v}$ TFA) at $2.5 \mathrm{~mL} / \mathrm{min}$, starting with $20 \% \mathrm{CH}_{3} \mathrm{CN}$, increasing to $32.5 \% \mathrm{CH}_{3} \mathrm{CN}$ in $20 \mathrm{~min}$, stepping to $42.5 \%$ $\mathrm{CH}_{3} \mathrm{CN}$ and increasing to $55 \%$ within $25 \mathrm{~min}$. About $1.2 \mathrm{mg}$ of compound $\mathbf{1}, 1.0 \mathrm{mg}$ of compound $\mathbf{2}$, and $0.6 \mathrm{mg}$ of compound 3 were isolated. The compounds eluted at $24.6 \mathrm{~min}(\mathbf{1}), 27.6 \mathrm{~min}(\mathbf{2})$, and $28.6 \mathrm{~min}$ (3) under analytical HPLC conditions as described previously [5].

$\left[\mathbf{A s p}^{\mathbf{3}},(\boldsymbol{E})-\mathbf{D h b}^{\mathbf{7}}\right] \mathbf{M C}-\mathbf{L Y}(\mathbf{1})$ : white, amorphous powder; UV $\left(\mathrm{H}_{2} \mathrm{O} / \mathrm{MeCN} / \mathrm{TFA}\right) \lambda_{\max } 232 \mathrm{~nm} ;{ }^{1} \mathrm{H}$ and ${ }^{13} \mathrm{C}$ NMR data see Table 1; HRESIMS $\mathrm{m} / \mathrm{z},[\mathrm{M}+\mathrm{H}]^{+}$ 988.5052 (calcd for $\mathrm{C}_{51} \mathrm{H}_{69} \mathrm{~N}_{7} \mathrm{O}_{13}, 988.5026$ ).

$\left[\mathbf{A s p}^{\mathbf{3}},(\boldsymbol{E})-\mathbf{D h b}^{\mathbf{7}}\right] \mathbf{M C}-\mathrm{HtyW}$ (2): white, amorphous powder; $\mathrm{UV}\left(\mathrm{H}_{2} \mathrm{O} / \mathrm{MeCN} / \mathrm{TFA}\right) \lambda_{\max } 222 \mathrm{~nm} ;{ }^{1} \mathrm{H}$ and ${ }^{13} \mathrm{C}$ NMR data see Table 2; HRESIMS $\mathrm{m} / z \quad[\mathrm{M}+\mathrm{H}]^{+}$ 1075.5133 (calcd for $\mathrm{C}_{57} \mathrm{H}_{70} \mathrm{~N}_{8} \mathrm{O}_{13}, 1075.5135$ ).

$\left[\mathbf{A s p}^{3},(\boldsymbol{E})-\mathbf{D h b}^{7}\right]$ MC-LW (3): white, amorphous powder; UV $\left(\mathrm{H}_{2} \mathrm{O} / \mathrm{MeCN} / \mathrm{TFA}\right) \lambda_{\max } 222 \mathrm{~nm} ;{ }^{1} \mathrm{H}$ NMR data see Table 3; HRESIMS $m / z[\mathrm{M}+\mathrm{H}]^{+} 1011.5172$ (calcd for $\mathrm{C}_{53} \mathrm{H}_{70} \mathrm{~N}_{8} \mathrm{O}_{12}, 1011.5186$ ).

\subsection{Protein Phosphatase Inhibition Assay}

A colorimetric protein phosphatase inhibition assay [34] was used to determine the $\mathrm{IC}_{50}$ of all the MC structural variants produced by Planktothrix strain No80. The catalytic subunit ( $\alpha$-isoform) of protein phosphatase 1 (PP1) from rabbit muscle (Sigma, Vienna, Austria) was diluted according to the manufacturer's instructions. The assay was carried out in 96-well microtiter plates. $10 \mu \mathrm{L}$ of enzyme dilution $(0.05 \mathrm{U}$ of PP-1) were added to $10 \mu \mathrm{L}$ of compound solution (dilution series; dissolved in $50 \%(\mathrm{v} / \mathrm{v})$ methanol). The enzyme was activated for $5 \mathrm{~min}$ at $37{ }^{\circ} \mathrm{C}$, and the reaction was started by adding $180 \mu \mathrm{L}$ of reaction buffer $\left(25 \mathrm{mM}\right.$ imidazole, $\mathrm{pH} 7.4,0.1 \mathrm{mg} \mathrm{mL}^{-1} \mathrm{BSA}$, $1 \mathrm{mM}$ DTT, $50 \mathrm{mM} \mathrm{NaCl}, 25 \mathrm{mM}$ p-nitrophenyl phosphate). To determine $100 \%$ PP-1 activity, $10 \mu \mathrm{L}$ of $50 \%$ (v/v) aqueous methanol was used instead of compound solution. For the $0 \%$ activity control, water was added instead of PP-1 enzyme dilution. MC-LR was used as a reference and gave $\mathrm{IC}_{50}$ values comparable to those reported previously for this compound [21, 34-36]. MC congeners were quantified by measuring the adsorption at 240 and $230 \mathrm{~nm}$ and using the molar extinction coefficient of MC-YR $(\varepsilon=41,100)$ [37] for all MC variants synthesized by strain No80. Incubation was for $40 \mathrm{~min}$ at $37^{\circ} \mathrm{C}$ and the microtiter plates were read at $405 \mathrm{~nm}$ with an ELISA plate reader (Jupiter, Asys Hitech, Eugendorf, Austria). All MC variants were tested in triplicate and the experimental data were evaluated following current recommendations [38]. $\mathrm{IC}_{50}$ values were interpolated from a four parameter logistic model fit using the software $\mathrm{EC}_{50}^{\text {calculator }}$ (see ESM for more details).

\section{Supporting Information}

All NMR and MS raw data as well as the Python script used to calculate the composition of possible MC congeners are available free of charge for download at http://dx.doi.org/10. 6084/m9.figshare.706367. Detailed evaluation and annotation of the tandem mass spectra, 1H NMR spectra, output of the Python script, and information on the $\mathrm{IC}_{50}$ calculation, are available in the online version of this article.

Acknowledgments TN thanks Cyano Biotech $\mathrm{GmbH}$ for support and permission to publish this manuscript. We thank R. Lethaus-Weiß for her help in cultivating the strain and extracting the biomass. K. Moosbrugger performed the PP-1 inhibition assay. Part of this work has been supported by the German Federal Ministry of Economics and Technology (KF2766301SB0), the Leibniz-Institut für Molekulare Phamakologie (FMP), the Austrian Science Fund (P24070), and the Austrian Climate Research Program (ACRP) project RADICAL (Risk Analysis of Direct and Indirect Climate effects on deep Austrian Lake Ecosystems). Support from M. Beerbaum (FMP) and W. Bermel (Bruker Biospin, Karlsruhe) in all NMRspectroscopic questions is gratefully acknowledged.

Open Access This article is distributed under the terms of the Creative Commons Attribution License which permits any use, distribution, and reproduction in any medium, provided the original author(s) and the source are credited. 


\section{References}

1. W. Carmichael, V. Beasley, D.L. Bunner, J.N. Eloff, I. Falconer, P. Gorham, K.I. Harada, T. Krishnamurthy, Y. Min-Juan, R.E. Moore, K. Rinehart, M. Runnegar, O.M. Skulberg, M. Watanabe, Toxicon 26, 971-973 (1988)

2. R.W. Zurawell, H. Chen, J.M. Burke, E.E.J. Prepas, Toxicol. Environ. Health B 8, 1-37 (2005)

3. M. Welker, H. Von Döhren, FEMS Microbiol. Rev. 30, 530-563 (2006)

4. G. Christiansen, W.Y. Yoshida, J.F. Blom, C. Portmann, K. Gademann, T. Hemscheidt, R. Kurmayer, J. Nat. Prod. 71, 1881-1886 (2008)

5. R. Kurmayer, G. Christiansen, J. Fastner, T. Börner, Environ. Microbiol. 6, 831-841 (2004)

6. R. Kurmayer, M. Gumpenberger, Mol. Ecol. 15, 3849-3861 (2006)

7. C. MacKintosh, K.A. Beattie, S. Klumpp, P. Cohen, G.A. Codd, FEBS 264, 187-192 (1990)

8. K. Harada, Chem. Pharm. Bull. 52, 889-899 (2004)

9. T. Mayumi, H. Kato, S. Imanishi, Y. Kawasaki, M. Hasegawa, K. Harada, J. Antibiot. 59, 710-719 (2006)

10. T.H.J. Niedermeyer, M. Strohalm, PLoS ONE 7, e44913 (2012)

11. C.O. Miles, M. Sandvik, S. Haande, H. Nonga, A. Ballot, Environ. Sci. Tech. 47, 4080-4087 (2013)

12. C.W. Diehnelt, S.M. Peterman, W.L. Budde, Trends Anal. Chem. 24, 622-634 (2005)

13. C.W. Diehnelt, N.R. Dugan, S.M. Peterman, W.L. Budde, Anal. Chem. 78, 501-512 (2006)

14. D. Tillett, E. Dittmann, M. Erhard, H. Von Döhren, T. Börner, B.A. Neilan, Chem. Biol. 7, 753-764 (2000)

15. M. Röttig, M.H. Medema, K. Blin, T. Weber, C. Rausch, O. Kohlbacher, Nucleic Acids Res. 39, 362-367 (2011)

16. C. Rausch, T. Weber, O. Kohlbacher, W. Wohlleben, D.H. Huson, Nucleic Acids Res. 33, 5799-5808 (2005)

17. G. Christiansen, J. Fastner, M. Erhard, T. Börner, E. Dittmann, J. Bacteriol. 185, 564-572 (2003)

18. C. Taylor, R.J. Quinn, M. Suganuma, H. Fujiki, Bioorg. Med. Chem. Lett. 6, 2113-2116 (1996)

19. J.R. Bagu, B.D. Sykes, M.M. Craig, C.F.B. Holmes, J. Biol. Chem. 272, 5087-5097 (1997)
20. B.M. Gulledge, J.B. Aggen, H. Eng, K. Sweimeh, A.R. Chamberlin, Bioorg. Med. Chem. Lett. 13, 2907-2911 (2003)

21. B.M. Gulledge, J.B. Aggen, A.R. Chamberlin, Bioorg. Med. Chem. Lett. 13, 2903-2906 (2003)

22. U. Piantini, O.W. Sorensen, R.R. Ernst, J. Am. Chem. Soc. 104, 6800-6801 (1982)

23. L. Braunschweiler, R.R. Ernst, J. Magn. Reson. 53, 521-528 (1983)

24. A. Bax, D.G. Davis, J. Magn. Reson. 65, 355-360 (1985)

25. A.A. Bothner-By, R.L. Stephens, J. Lee, C.D. Warren, R.W. Jeanloz, J. Am. Chem. Soc. 106, 811-813 (1984)

26. A. Bax, D.G. Davis, J. Magn. Reson. 63, 207-213 (1985)

27. A. Bax, R.H. Griffey, B.L. Hawkins, J. Am. Chem. Soc. 105, 7188-7190 (1983)

28. H. Kessler, P. Schmieder, M. Kurz, J. Magn. Reson. 85, 400-405 (1989)

29. L. Lerner, A. Bax, J. Magn. Reson. 69, 375-380 (1986)

30. A. Bax, S. Subramanian, J. Magn. Reson. 67, 565-569 (1986)

31. A. Bax, M.F. Summers, J. Am. Chem. Soc. 108, 2093-2094 (1986)

32. G. Christiansen, C. Molitor, B. Philmus, R. Kurmayer, Mol. Biol. Evol. 25, 1695-1704 (2008)

33. R. Andersen, Algal Culturing Techniques, (Elsevier, Academic Press, Amsterdam, New York 2005), p. 596

34. J. An, W.W. Carmichael, Toxicon 32, 1495-1507 (1994)

35. R.M. Dawson, Toxicon 36, 953-962 (1998)

36. N.R. Monks, S. Liu, Y. Xu, H. Yu, A.S. Bendelow, J.A. Moscow, Mol. Cancer Ther. 6, 587-598 (2007)

37. J.F. Blom, J.A. Robinson, F. Jüttner, Toxicon 39, 1923-1932 (2001)

38. B. Beck, Y. Chen, B.J. Eastwood, M.W. Farmen, S.J. Iturria, P.W. Iversen, S.D. Kahl, R.A. Moore, B.D. Sawyer, in Assay Guidance Manual, ed. by G.S. Sittampalam, N. Gal-Edd, M. Arkin, D. Auld, C. Austin, B. Bejcek, M. Glicksman, J. Inglese, V. Lemmon, Z. Li, J. McGee, O. McManus, L. Minor, A. Napper, T. Riss, O.J. Joseph Trask, J. Weidner. Assay Operations for SAR Support, (Eli Lilly \& Company and the National Center for Advancing Translational Sciences, Bethesda, 2012), http://www. ncbi.nlm.nih.gov/books/NBK91994/, Accessed 05.03.2013 